\title{
Correction to: Daily Worry in Trauma-Exposed Afghan Refugees: Relationship with Affect and Sleep in a Study Using Ecological Momentary Assessment
}

\author{
Theresa Koch ${ }^{1,2} \cdot$ Alexandra LiedI $^{1,2} \cdot$ Keisuke Takano $^{1} \cdot$ Thomas Ehring $^{1}$
}

Published online: 8 November 2021

(c) The Author(s) 2021

\section{Correction to: \\ Cognitive Therapy and Research (2020) 44:645-658 https://doi.org/10.1007/s10608-020-10091-7}

The article "Daily Worry in Trauma-Exposed Afghan Refugees: Relationship with Affect and Sleep in a Study Using Ecological Momentary Assessment", written by Theresa Koch, Alexandra Liedl, Keisuke Takano, Thomas Ehring, was originally published electronically on the publisher's internet portal on 13 March 2020 without open access. With the author(s)' decision to opt for Open Choice the copyright of the article changed on 12 October 2021 to (C) The Author(s) 2020 and the article is forthwith distributed under a Creative Commons Attribution 4.0 International License, which permits use, sharing, adaptation, distribution and reproduction in any medium or format, as long as you give appropriate credit to the original author(s) and the source, provide a link to the Creative Commons licence, and indicate if changes were made. The images or other third party material in this article are included in the article's Creative Commons licence, unless indicated otherwise in a credit line to the material. If material is not included in the article's Creative Commons licence and your intended use is not permitted by statutory regulation or exceeds the permitted use, you will need to obtain permission directly from the copyright holder. To view a copy of this licence, visit http:// creativecommons.org/licenses/by/4.0.

The original article has been corrected.

Open Access This article is licensed under a Creative Commons Attribution 4.0 International License, which permits use, sharing, adaptation, distribution and reproduction in any medium or format, as long as you give appropriate credit to the original author(s) and the source, provide a link to the Creative Commons licence, and indicate if changes were made. The images or other third party material in this article are included in the article's Creative Commons licence, unless indicated otherwise in a credit line to the material. If material is not included in the article's Creative Commons licence and your intended use is not permitted by statutory regulation or exceeds the permitted use, you will need to obtain permission directly from the copyright holder. To view a copy of this licence, visit http://creativecommons.org/licenses/by/4.0/.

Publisher's Note Springer Nature remains neutral with regard to jurisdictional claims in published maps and institutional affiliations.

The original article can be found online at https://doi.org/10.1007/ s10608-020-10091-7.

Theresa Koch

theresa.koch@psy.lmu.de

1 Division of Clinical Psychology and Psychological

Treatment, Department of Psychology, LMU Munich,

Leopoldstr. 13, 80802 Munich, Germany

2 Refugio München, Munich, Germany 